\title{
Vibrio vulnificus cytolysin induces hyperadhesiveness of pulmonary endothelial cells for neutrophils through endothelial P-selectin: a mechanism for pulmonary damage by Vibrio vulnificus cytolysin
}

\author{
Byeong-Soo $\mathrm{Kim}^{1,2}$ and Jong-Suk Kim ${ }^{1,3}$ \\ ${ }^{1}$ Department of Biochemistry, Chonbuk National University Medical \\ School and Institute of Cardiovascular Research, Chonju 560-756, \\ Republic of Korea \\ ${ }^{2}$ Present address: Department of Clinical Pathology, Sohae Col- \\ lege, Kunsan 573-755, Republic of Korea \\ ${ }^{3}$ Corresponding author; Tel, +82-63-270-3085; \\ Fax, +82-63-274-9833; E-mail, jsukim@moak.chonbuk.ac.kr
}

Accepted 21 August 2002

Abbreviation: HU, hemolytic Unit; PBS, phosphate-buffered saline IL-1, interleukin-1; TNF, tumor necrosis factor; ICAM-1, intercellular adhesion molecule-1

\begin{abstract}
s
Vibrio vulnificus cytolysin forms transmembrane pores that are permeable to calcium ions in pulmonary endothelial cells, and has been suggested as an important virulence factor that sequestrate neutrophils primarily in the lung. To elucidate the mechanism we investigated whether the cytolysin affect the expression of endothelial P-selectin and adhesiveness of pulmonary endothelial cells for neutrophils. The cytolysin increased the adhesiveness of CPAE cell, a pulmonary endothelial cell line, for neutrophils in a concentrationand time-dependent manner. The increase of adhesiveness occurred within several minutes after the cytolysin exposure, persisted up to $90 \mathrm{~min}$, and was not affected by cycloheximide. Furthermore, flow cytometric analyses showed that cytolysin enhanced the level of P-selectin on CPAE cell surface. Therefore, these results suggest that the cytolysin-induced hyperadhesiveness of pulmonary endothelial cells for neutrophils is mediated by the mobilization of endothelial P-selectin to the cell surface.
\end{abstract}

Keywords: Vibrio vulnificus cytolysin, P-selectin, endothelial cells, neutrophils

\section{Introduction}

Vascular endothelial cells respond to a variety of inflammatory mediators including hormones, cytokines, oxidants, bacterial toxins, and various physiologically active compounds (Zimmerman et al., 1985; Schleimer and Rutledge, 1986; Patel et al., 1991; Weller et al., 1992; Palmblad et al., 1994; Krüll et al., 1996). Endothelial cells, by being a first and only available cells in the vasculature, are ready target cells leading to the pathogenesis of human inflammatory disorders. Among the many roles, endothelial cells participate in the neutrophil infiltration to inflammatory sites by providing adhesive molecules for the docking of circulating leukocytes. Endothelial cells are known to express various adhesion molecules, which may regulate neutrophil adhesion such as selectins [E-selectin, endothelialleukocyte adhesion molecule-1 (ELAM-1) or P-selectin, granule membrane protein-140 (GMP-140)], vascular cell adhesion molecule-1 (VCAM-1), and intercellular adhesion molecule-1 (ICAM-1) (Bevilacqua et al., 1989; Bonfanti et al., 1989; Lorant et al., 1991; Larsen et al., 1992; Bevilacqua and Nelson, 1993; Calos and Harlan, 1994; Boyce et al., 2002). Recent studies show that vascular endothelial cells actively participate in the genesis of inflammatory and systemic alterations occurring in sepsis sustained by gram-negative bacteria. These results suggest that alteration of endothelial cell functions may be primarily associated with the pathogenesis of sepsis in gram-negative bacterial infection.

Vibrio vulnificus is known to be a life-threatening pathogen that causes septicemia and serious wound infection in human. $V$. vulnificus infection is characterized by the high fatality rates of $70 \%$ and the primary attack against people who are immunocompromised or have underlying diseases such as liver cirrhosis (Blakes et al., 1979; Park et al., 1991). Kreger and Lockwood (1981) demonstrated that the cytolysin present in culture medium of $V$. vulnificus showed hemolytic activity and cytotoxicity for mammalian cells in culture, and acted as a vascular permeability factor. Even submicrogram amount of the cytolysin is fatal to mice when injected intravenously (Gray and Kreger, 1985). Furthermore, recent data show that $V$. vulnificus cytolysin activates mammalian cells through the stimulation of nitric oxide synthase (NOS) as well as guanlyate cyclase (Kook et al., 1996; Kang et al., 2002). These reports suggest that the cytolysin is the major factor in the pathogenesis of $V$. vulnificus infections. However, the exact pathogenic mechanism of the cytolysin in the progress of the 
disease is still not known.

The cytolysin-induced acute lung injury, was characterized by extensive perivascular edema and leukocyte infiltration in perivascular space (Song et al., 1998). The cytolysin increase vascular permeability and sequestrate neutrophil in the lung of mice (Park et al., 1996) where the cytolysin bound to pulmonary endothelial cells induced the cell death through the formation of transmembrane pores on plasma membrane (Kim, 1997). These findings suggest that pulmonary endothelial cells might be important target cells of the cytolysin in the pathogenesis of $V$. vulnificus infection.

In this study, we investigated the effects of $V$. vulnificus cytolysin on functions of pulmonary endothelial cells such as endothelial adhesivity toward neutrophils. Here, we present the first evidence that $V$. vulnificus cytolysin induces hyperadhesiveness of pulmonary endothelial cells for neutrophils through endothelial P-selectin, causing pulmonary damage by $V$. vulnificus cytolysin.

\section{Materials and Methods}

\section{Materials}

BSA, hydrogen peroxide $\left(\mathrm{H}_{2} \mathrm{O}_{2}\right)$, cyclohexhaximide, dodecyltrimethyl-ammonium bromide, dianisidine dihydrochlroride, Dulbecco's phosphate buffered saline (PBS), fluorescein isothiocyanatelabeled antimouse lgG, and Hank's balanced salt solution (HBSS) were purchased from Sigma (St. Louis. MO.). Anti-P-selectin monoclonal antibody (CTB201) was obtained from Santa Cruz Biotechnology (Santa Cruz, CA.). Percoll was from Pharmacia (Mil-waukee, WI.), Fura-2/acetoxymethyl ester (Fura-2/AM) was from Molecular Probes (Eugene, OR.), heart infusion broth and RPMI 1640 was from Gibco (Grand Island, NY.). All other reagents were of the highest purity grade available.

\section{Endothelial cell culture}

The pulmonary endothelial cell line, CPAE (ATCC CCL 209) was obtained from Korea Cell Bank (College of Medicine, Seoul National University, Korea). CPAE cells were cultured in culture media [RPMI 1640 supplemented with $15 \%$ fetal bovine serum, penicillin (100 units $/ \mathrm{ml})$, streptomycin $(0.1 \mathrm{mg} / \mathrm{ml})$ and ampotericin B $(0.25 \mathrm{mg} / \mathrm{ml})]$ in a humidified atmosphere of $5 \% \mathrm{CO}_{2}$. When CPAE cells (30-32 passages) had grown to confluence, adherent cells were removed under sterile conditions from the culture flask by gentle trypsinization (0.05\% trpysin, $0.02 \%$ EDTA). The cell suspensions were immediately used for various experiments.

\section{Purification of $\boldsymbol{V}$. vulnificus cytolysin}

A virulent strain of $V$. vulnificus E4125 was kindly supplied by Dr. M. H. Kothary (Department of Microbiology,
Virulence Assessment Branch, Center for Food Safety and Applied Nutrition, Food and Drug Ad-ministration, Washington D. C.). The strain was cultured in the heart infusion diffusate broth as described by Kreger et al. (1988). Cytolysin was purified to homogeneity from the culture supernatant by a modification of the method developed by Kim et al. (1992).

\section{Isolation of neutrophils}

Neutrophils suspensions were prepared from EDTA venous blood of healthy rats using the modification of the method of Wright et al. (1988). The neutrophils were isolated by discontinuous plasma Percoll gradients using lipopolysaccharide-free reagents $[55 \% / 70 \%$ Percoll (v/v) in $10 \mathrm{mM}$ Hepes-buffered HBSS $(\mathrm{pH} 7.3)$ without $\mathrm{Ca}^{2+}$ or $\mathrm{Mg}^{2+}$.

\section{Neutrophil-CPAE cell adherence assay}

The adherence of neutrophils to endothelial cells was determined with the cytolysin-treated CPAE cell monolayers in 24-well culture plate. Confluent CPAE cells were washed twice with $10 \mathrm{mM}$ Hepes-buffered HBSS (pH 7.3) containing $5 \mathrm{mM}$ glucose. The cytolysin added to CPAE cell monolayers of each wells and incubated at $37^{\circ} \mathrm{C}$. At the end of each incubation period, endothelial cells were fixed with $1 \%$ paraformaldehyde/PBS at room temperature for $15 \mathrm{~min}$. After washing of CPAE cells three times with $10 \mathrm{mM}$ Hepes-buffered HBSS $(\mathrm{pH} 7.3)$ containing $5 \mathrm{mM}$ glucose, neutrophil suspensions (1 $\mathrm{x}$ $10^{6} \mathrm{cells} /$ well) were added to each well. The cell mixture was incubated at $37^{\circ} \mathrm{C}$ for $60 \mathrm{~min}$. CPAE cell monolayers were then washed three times with warm PBS containing $5 \mathrm{mM}$ glucose to remove nonadherent neutrophils. The number of neutrophils bound to CPAE cell monolayers was determined by a modified myeloperoxidase assay of Park et al. (19). Briefly, $0.5 \mathrm{ml}$ of dodecyltrimethylammonium bromide $[0.5 \% \quad(\mathrm{w} / \mathrm{v})]$ in modified PBS (PBS without $\mathrm{Ca}^{2+}$ and $\mathrm{Mg}^{2+}, \mathrm{pH}$ 6.0) was added to the wells for $30 \mathrm{~min}$ at room temperature to lyse all cells, which caused the release of myeloperoxidase from the neutrophils adherent to endothelial cells. After adding dianisidine dihydrochlroride $(0.2 \mathrm{mg} / \mathrm{ml})$ and $\mathrm{H}_{2} \mathrm{O}_{2}$ $(0.4 \mathrm{mM})$ in modified PBS to a total volume $1 \mathrm{ml}$ of the reaction mixture for $20 \mathrm{~min}$ at room temperature, absorbances was read at $450 \mathrm{~nm}$ in spectrophotomer (Beckman, DU-65). Absorbance in the lysate reflects the number of endothelial cell-bound neutrophils. Percentage of neutrophil adhesion was calculated as myeloperoxidase enzyme activities in the lysate in relation to their total activities added. Heated cytolysin (toxin kept at $37^{\circ} \mathrm{C}$ overnight) was designed as control toxin, because its hemolytic activity (HU) was lost rapidly at $37^{\circ} \mathrm{C}$.

\section{Flow cytomatric analysis for P-selectin on CPAE cell} Confluent CPAE cells were washed twice with $10 \mathrm{mM}$ 


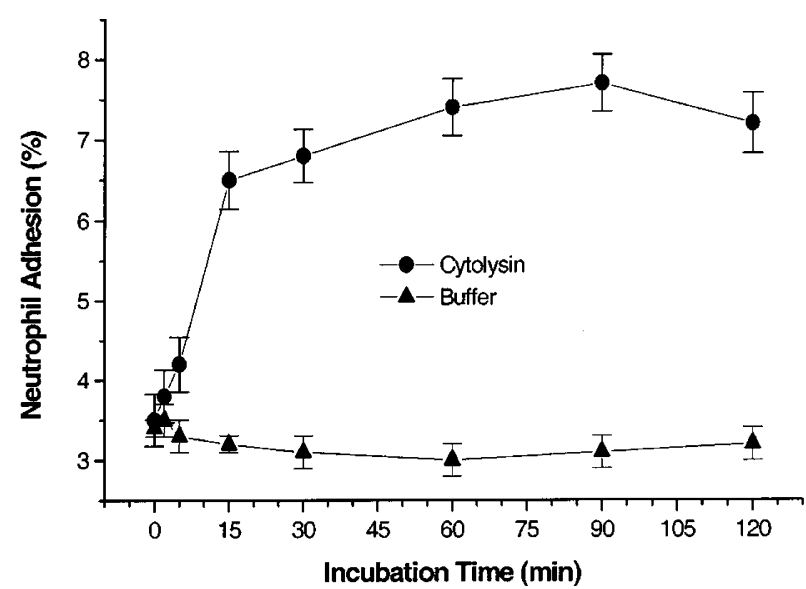

Figure 1. Kinectics of hyperadhesiveness of endothelial cells for neutrophils by $V$. vulnificus cytolysin. Endothelial cells were incubated with $1 \mathrm{HU} / \mathrm{ml}$ of the cytolysin at $37^{\circ} \mathrm{C}$ for the indicated times. The cells were fixed with $1 \%$ paraformaldehyde and neutrophils were added to endothelial cells. Percentage of neutrophil adhesion was determined as described in Materials and Methods. Each value depicts the mean \pm SE obtained from five separate experiments.

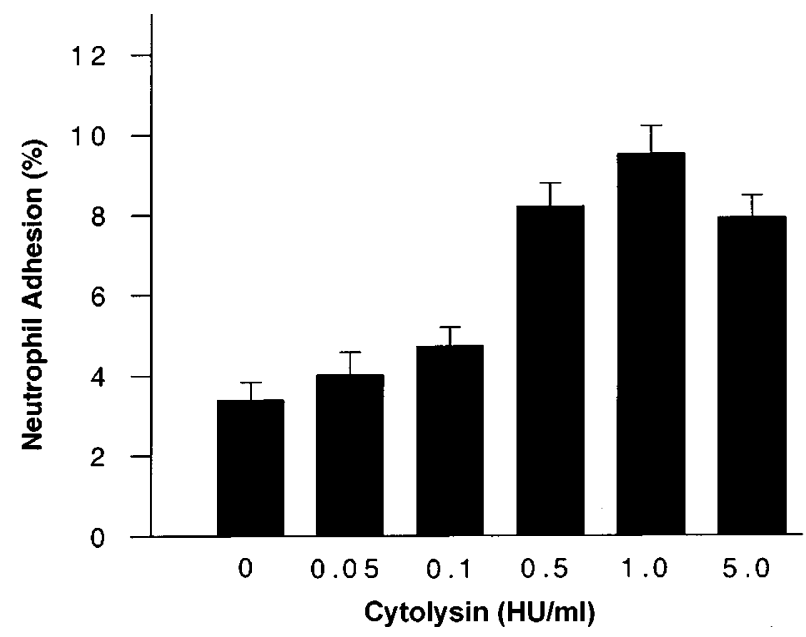

Figure 2. Hyperadhesiveness of endothelial cells for neutrophils by $V$. vulnificus cytolysin at the various concentrations. Endothelial cells were incubated with the cytolysin at $37^{\circ} \mathrm{C}$ for $90 \mathrm{~min}$. The cells were fixed with $1 \%$ paraformaldehyde and neutrophils were added to endothelial cells. Percentage of neutrophil adhesion was determined as described in Materials and Methods. Each value depicts the mean \pm SE obtained from five separate experiments.

Hepes-buffered HBSS (pH 7.3) containing $5 \mathrm{mM}$ glucose, trypsinized and incubated with $1 \mathrm{U} / \mathrm{ml}$ of cytolysin at $37^{\circ} \mathrm{C}$ for 1-2 $\mathrm{h}$. The cells were washed and incubated with antiP-selectin monoclonal antibodies $(10 \mu \mathrm{g} / \mathrm{ml})$ for $30 \mathrm{~min}$ in ice. After washing with phosphate-buffered saline, the cells were stained with fluorescein isothiocyanate-labeled antimouse IgG and subjected to a flow cytometric analysis.

\section{Results and Discussion}

Previous results had demonstrated that $V$. vulnificus

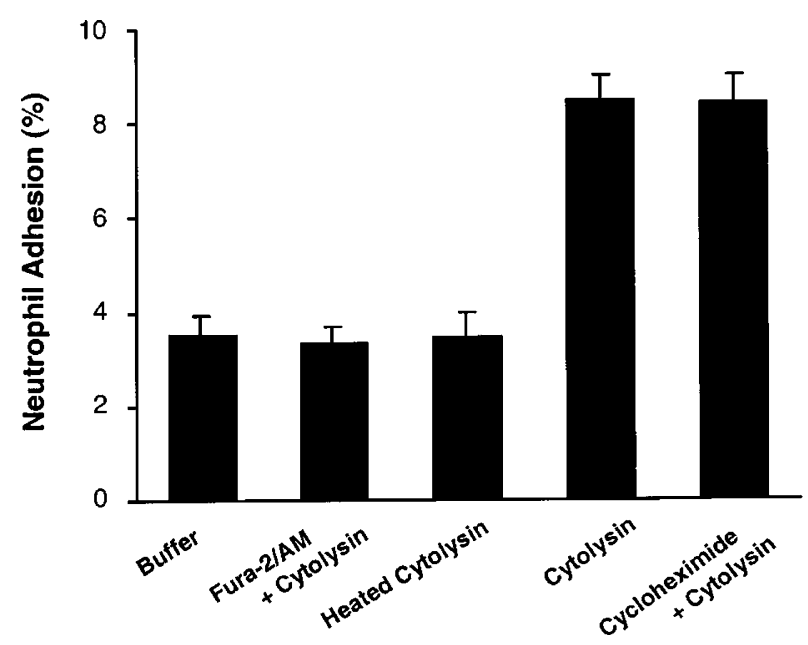

Figure 3. Effect of cycloheximide and heating on hyperadhesiveness of endothelial cells for neutrophils by $V$. vulnificus cytolysin. Endothelial cells were preincubated with $10 \mu \mathrm{g} / \mathrm{ml}$ cycloheximide or $3 \mu \mathrm{M}$ Fura-2/AM at $37^{\circ} \mathrm{C}$ for $15 \mathrm{~min}$, and the cells were treated with $1 \mathrm{HU} / \mathrm{ml}$ cytolysin in the presence of cycloheximide or Fura-2/AM at $37^{\circ} \mathrm{C}$ for $90 \mathrm{~min}$. After treatment, neutrophils were added to endothelial cells without paraformaldehyde fixation. Adhesion study for the heated cytolysin was performed by the same method except for the preincubation of cycloheximide. Percentage of neutrophil adhesion was determined as described in Materials and Methods. Each value depicts the mean \pm SE obtained from five separate experiments.

cytolysin induced the elevation of intracellular $\left[\mathrm{Ca}^{2+}\right]_{i}$ in pulmonary endothelial cells (Rho et al., 2002). $\mathrm{Ca}^{2+}$ is known to play an essential role in the stimulation of endothelial cell function, such as hyperadhesion activity for neutrophils, secretion of adhesion molecules, and production of eicosanoids (Grimminger et al., 1990; Zimmerman et al., 1990; Sugama et al., 1992; Palmblad et al., 1994). Therefore, cytolysin-induced increase of $\left[\mathrm{Ca}^{2+}\right]_{i}$ could likely affect the function of endothelial cells. In this study pulmonary endothelial cell adhesiveness for neutrophils was studied using endothelial cell monolayer.

The cytolysin increased endothelial adhesiveness for neutrophils in a time-dependent manner (Figure 1). The endothelial adhesivity increased rapidly at $15 \mathrm{~min}$ after the cytolysin exposure, and the response was sustained up to $90 \mathrm{~min}$. When endothelial cell monolayers were treated with various concentrations of cytolysin, endothelial hyperadhesiveness was induced in a dose-dependent manner, with a maximal value at $1 \mathrm{HU} / \mathrm{ml}$ of cytolysin (Figure 2). At these experimental conditions, there was no endothelial cell lysis in a view of LDH leakadege from endothelial monolayer (data not shown). These results indicate that the cytolysin causes the expression of adhesion molecules from pulmonary endothelial cells. Possible effect of contaminating endotoxin that are known to induce the adhesion of neutrophils to endothelial cells was ruled out. The cytolysin preparation was heat treated to inactivate cytolysin but endotoxin. As shown at Figure 3, the heated cytolysin had no effect on the adhesion of neutrophils. This result clearly suggests that the hypera- 
dhesiveness of endothelial cells for neutrophils was evoked by the cytolysin peptide itself and not by contaminating endotoxin.

The adhesion molecules expressed by the cytolysin can be either newly synthesized or secreted from intracellular stores. In order to determine whether the hyperadhesiveness of the cytolysin-treated endothelial cells toward neutrophils is dependent on protein synthesis, the influence of cyclohexhaximide on adhesive effect of the cytolysin was studied. Treatment of endothelial cells with cycloheximide did not prevent neutrophil adhesion to the cytolysin-challenged endothelial cells (Figure 3). This finding suggests that neutrophil adhesion mediated by the cytolysin is not dependent on protein synthesis. It usually takes hours rather than minutes to synthesize the new adhesion molecules in target cells after stimuli challenge. Thus, this result is closely correlated with the finding that the endothelial adhesivity induced rapidly within 15 min after the cytolysin challenge.

For neutrophil adhesion to activated endothelial cells, cell-cell adhesion molecules on endothelial cell surfaces are P-selectin, E-selectin, and ICAM-1 (Bevilacqua and Nelson, 1993; Carlos and Harlan, 1994; Boyce et al., 2002). E-selectin is cytokine-inducible adhesion molecules expressed in endothelial cells through de novo protein synthesis, which is induced by endotoxin or inflam-matory cytokine interleukin-1 (IL-1) or tumor necrosis factor (TNF). This expression peaks in 4-6 h, declines to basal levels by 24-48 $\mathrm{h}$, and requires de novo RNA and protein synthesis (Lorant et al., 1991). Unlike E-selectin, P-selectin is synthesized constitutively and stored intracellularly in endothelial cells. Thus, Pselectin (granule membrane protein-140, GMP-140) of en-dothelial cell secretory granules is rapidly redistributed to the plasma membrane during cellular activation and degranulation, which requires extracellular calcium ions (Geng et al., 1990). In our experimental conditions, buffer change in $\left[\mathrm{Ca}^{2+}\right]_{i}$ with Fura-2/AM abrogated neutrophil hyperadhesion mediated by the cytolysin (Figure 3), suggesting that the hyperadhesive effect of cytolysin on endothelial cells is associated with calciumdependent redistribution of $\mathrm{P}$ selectin on endothelial cell surface. A variety of mediators, thrombin and histamine have been shown to induce rapid surface expression of $P$-selectin, and the expression of P-selectin at the cell surface is short lived, declining substantially within several minutes (Bonfanti et al., 1989; Sugama et al., 1992). However, there are reports that new $P$-selectin synthesis may be induced by cytokines such as IL-1 and TNF in a manner similar to that of E-selectin (Palmblad et al., 1994). Induction of ICAM-1 by the cytokines (IL-1 and TNF) as well as endotoxin requires de novo protein synthesis secondary to the transcription of the ICAM-1 mRNA as E-selectin. In this study, endothelial adhesivity increased within

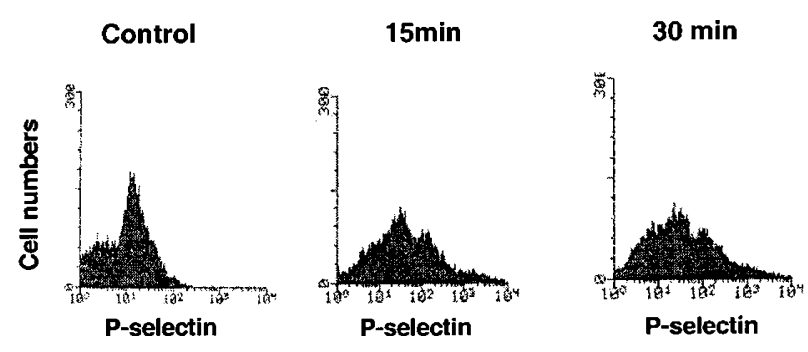

Figure 4. Up-regulation of P-selectin on endothelial cells by $V$. vulnificus cytolysin. Endothelial cells were trypsinized and incubated with $1 \mathrm{HU} / \mathrm{ml}$ of cytolysin. After indicated time, the cells were washed, stained with anti-pselectin antibody and analyzed with flow cytometry.

several minutes after the cytolysin exposure, and the response was sustained up to $90 \mathrm{~min}$. The cytolysininduced neutrophil adhesion was protein synthesisindependent since the cytolysin-induced adhesion was not inhibited by cycloheximide pretreatment. Thus, the previous results strongly indicate that the cytolysin might induce the expression of adhesion molecules, such as P-selectin from storage granules of endothelial cells. We next examined whether $P$-selectin is associated with the cytolysin-induced hyperadhesiveness of endothelial cells for neutrophils. Flow cytometric analyses showed upregulation of $\mathrm{P}$-selectin on surface of endothelial cells by the cytolysin (Figure 4). These results suggest that the cytolysin can induce mobilization of endothelial $\mathrm{P}$ selectin to the endothelial cell surface.

In conclusion, the results of this study indicate that $V$. vulnificus cytolysin induces the hyperadhesiveness of pulmonary endothelial cells for neutrophils, which is mediated by the cytolysin-induced mobilization of endothelial P-selectin to the cell surface. The hyperadhesive effects of the cytolysin appear to be largely mediated by an interaction between P-selectin on endothelial cells and a ligand on neutrophils.

\section{Acknowledgments}

This work was supported in part by the 7th grant from Kye-Nam, Jae-Jung Memorial Fund.

\section{References}

Bevilacqua MP, Stengelin S, Gimbrone Jr MA, Seed B. Endothelial adhesion molecule 1: an inducible receptor for neutrophils related to complement regulatory proteins and lectins. Science 1989;243:1160-5

Bevilacqua MP, Nelson RM. Selectin. J Clin Invest 1993; 91:379-87

Blakes PA, Merson H, Weave RE, Aollis DG, Heublein PC. Disease caused by a marine Vibrio: Clinical characteristics and epidemiology. N Engl J Med 1979;300:1-5

Bonfanti R, Furie BC, Furie B, Wagner DD. PADGEM (GMP- 
140 ) is a component of Weibel-Palade bodies of human endothelial cells. Blood 1989;73:1109-12

Boyce JA, Mellor EA, Perkins B, Lim YC, Luscinskas FW. Human mast cell progenitors use alpha4-integrin, VCAM-1, and PSGL-1 E-selectin for adhesive interactions with human vascular endothelium under flow conditions. Blood 2002;99: 2890-6

Carlos TM, Harlan JM. Leukocyte-endothelial adhesion molecules. Blood 1994;84:2068-101

Geng JG, Bevilacqua MP, Moore KL, Mclntyre TM, Prescott SM, Kim JM, Bliss GA, Zimmerman GA, McEver RP. Rapid neutrophil adhesion to activated endothelium mediated by GMP-140. Nature 1990; 343:757-60

Gray LD, Kreger AS. Purification and characterization of an extracellular cytolysin produced by Vibrio vulnificus. Infect Immun 1985;48:62-72

Gray LD, Kreger AS. Mouse skin damage caused by cytolysin from Vibrio vulnificus and by Vibrio vulnificus infection. J Infect Dis $1989 ; 155: 236-41$

Grimminger F, Thomas M, Obernitz R, Walmrath D, Bhakdi S, Seeger W. Inflammatory lipid mediator generation elicited by viable hemolysin-forming Escherichia coli in lung vasculature. J Exp Med 1990;172:1115-25

Grimminger F, Sibelius U, Bhakdi S, Suttorp N, Seeger W. Escherichia coli hemolysin is a potent inducer of phosphoinositide hydrolysis and related metabolic responses in human neutrophils. J Clin Invest 1991; 88:1531-9

Larsen GR, Sake D, Ahern TJ, Shaffer M. P-selectin and Eselectin. J Biol Chem 1992; 267:11104-10

Lorant DE, Patel KD, McIntyre TM, McEver RP, Prescott SM, Zimmernan GA. Coexpression of GMP-140 and PAF by endothelium stimulated with histamine or thrombin: a juxtacrine system for adhesion and activation of neutrophils. $J$ Cell Biol 1991;115:223-34

McEver RP, Cummings RD. Role of PSGL-1 binding to selectins in leukocyte recruitment. J Clin Invest 1997;100:S97S103

Moore KL, Patel KD, Bruehl RE, Fugang L, Johnson DA, Lichenstein HS, Cummings RD, Bainton DF, McEver RP. Pselectin glycoproteins ligand-1 mediates rolling of human neutrophils on P-selectin. J Cell Biol 1995;128:661-71

Kang MK, Jhee EC, Koo BS, Yang JY, Park BH, Kim JS, Rho HW, Kim HR, Park JW. Induction of nitric oxide synthase expression by Vibrio vulnificus cytolysin. Biochem Biophys Res Commun 2002;290:1090-5

Kim JS. Cytotoxicity of Vibrio vulnificus cytolysin pulmonary endothelial cells. Exp Mol Med 1997;29:117-21

Kim HR, Park SD, Park JW, Jeong MH, Kim JS, Park BH. Purification and characterization of cytolysin produced by Vibrio vulnificus. Kor J Biochem 1992;24:7-11

Kook H, Lee SE, Balk YH, Chung SS, Lee JH. V. vulnificus hemolysin dilates rat thoracic aorta by activating guanylate cyclase. Life Sci 1996;59:41-7

Kreger AS, Lockwood D. Detection of extracellular toxin(s) produced by Vibrio vulnificus. Infect Immun 1981;33:583-90

Kreger AS, Kothary MH, Gray LD. Cytolytic toxins of Vibrio vulnificus and Vibrio damsela. Methods Enzymol 1988;165:176-89

Krüll M, Dold C, Hippentiel S, Rosseau S, Lohmeyer J, Suttorp N. Escherichia coli hemolysin and Staphylococcus aureus toxin potently induce neutrophil adhesion to cultured human endothelial cells. J Immunol 1996;157: 4133-40

Palmblad J, Lerner R, Larsson SH. Signal transduction mechanism for leukotriene B4 induced hyperadhesiveness of endothelial cells for neutrophils. J Immunol 1994;152:262-9

Park SD, Shon HS, Joh NJ. Vibrio vulnificus septicemia in Korea: clinical and epidemiologic findings in seventy pationts. J Am Acad Dermatol 1991;24:397-403

Park JW, Ma SN, Song ES, Song $\mathrm{CH}$, Chae MR, Park BH, Rho HW, Park SD, Kim HR Pulmonary damage by Vibrio vulnificus cytolysin. Infect Immun 1996;64:2873-4

Patel KD, Zimmernan GA., Prescott SM., McEver RP, Mclntyre TM. Oxygen radicals induce human endothelial cells to express GMP-140 and bind neutrophils. J Cell Biol 1991;112:749-59

Rho HW, Choi MJ, Lee JN, Park JW, Kim JS, Park BH, Sohn HS, Kim HR. Cytotoxic mechanism of Vibrio vulnificus cytolysin in CPAE cells. Life Sci 2002;70:1923-34

Schleimer RP, Rutledge BK. Cultured human vascular endothelial cells aquire adhesiveness for neutrophils after stimulation with interleukin 1, endotoxin, and tumor promoting phorbol diesters. J Immunol 1986;136:649-54

Song $\mathrm{CH}$, Park JW, Kim DI, Cha SH, Kim HT, Lee MS, Kim HR, Park SD. Histopathologic study on the toxicity of cytolysin produced by Vibrio vulnificus. Kor J Anat 1998;31:127-36

Sugama Y, Tiruppathi C, Janakidevi K, Andersen TT, Fenton II JW, Malik AB Thrombin-induced expression of endothelial P-selectin and intracellular adhesion molecule-1: A mechanism for stabilizing neutrophil adhesion. J Cell Biol 1992; 119:935-44

Weller A, Isenmann S, Vestweber D. Cloning of the mouse endothelial selectins. Expression of both $\mathrm{E}$ - and P-selectin is inducible by tumor necrosis factor. J Biol Chem 1992; 267:15176-83

Wright DG. Human neutrophil degranulation. Methods Enzymol 1988;162:538-51

Zimmernan GA., Mclntyre TM, Prescott SM. Thrombin stimulates the adherence of neutrophils to human endothelial cells in vitro. J Clin Invest 1985;76:2235-46

Zimmernan GA, Mclntyre TM, Mehra M, Prescott SM. Endothelial cell-associated platelet-activating factor: a novel mechanism for signaling intercellular adhesion. J Cell Biol 1990;110:529-40 